\title{
Small Changes in Ambient Temperature Cause Large Changes in 3,4-Methylenedioxymethamphetamine (MDMA)-Induced Serotonin Neurotoxicity and Core Body Temperature in the Rat
}

\author{
Jessica E. Malberg and Lewis S. Seiden \\ University of Chicago, Department of Pharmacological and Physiological Sciences, Chicago, Illinois 60637
}

The amphetamine derivative 3,4-methylenedioxymethamphetamine (MDMA) is a drug of abuse and has been shown to be neurotoxic to 5-HT terminals in many species. MDMAengendered neurotoxicity has been shown to be affected by both ambient temperature and core body temperature. We now report that small $\left(2^{\circ} \mathrm{C}\right)$ changes in ambient temperature produce changes in core temperature in MDMA-treated rats, but the same changes in ambient temperature do not affect core temperature of saline-treated animals. Furthermore, increases in core temperature of MDMA-treated animals increase neurotoxicity. Rats were given MDMA (20 or $40 \mathrm{mg} / \mathrm{kg}$ ) or saline and placed in an ambient temperature of $20,22,24,26,28$, or $30^{\circ} \mathrm{C}$ using a novel temperature measurement apparatus that controls ambient temperature $\pm 0.5^{\circ} \mathrm{C}$. Two weeks after MDMA treatment, the rats were killed, and regional 5-HT and 5-hydroxyindole acetic acid levels were analyzed as a measure of neurotoxicity. Rats treated with MDMA at 20 and $22^{\circ} \mathrm{C}$ showed a hypothermic core temperature response. Treatment with MDMA at 28 and $30^{\circ} \mathrm{C}$ produced a hyperthermic response. At ambient temperatures of $20-24^{\circ} \mathrm{C}$, neurotoxicity was not observed in the frontal cortex, somatosensory cortex, hippocampus, or striatum. At ambient temperatures of $26-30^{\circ} \mathrm{C}$, neurotoxicity was seen and correlated with core temperature in all regions examined. These data indicate that ambient temperature has a significant affect on MDMA neurotoxicity, core temperature, and thermoregulation in rats. This finding has implications on both the temperature dependence of the mechanism of MDMA neurotoxicity and human use because fatal hyperthermia is associated with MDMA use in humans.

Key words: MDMA; amphetamine; core body temperature; ambient temperature; neurotoxicity; 5-HT; thermoregulation
3,4-Methylenedioxymethamphetamine (MDMA) is a substituted amphetamine that is abused (Steele et al., 1994) and has been shown to be neurotoxic to the 5-HT system in a number of species (Commins et al., 1987b; Schmidt, 1987). Evidence indicating MDMA neurotoxicity includes decreases in tryptophan hydroxylase (Stone et al., 1988), decreases in 5-HT and 5-hydroxyindole acetic acid (5-HIAA) levels (Schmidt et al., 1986), decreases in 5-HT uptake sites (Battaglia et al., 1988), and evidence of 5-HT terminal degeneration (Commins et al., 1987b; O'Hearn et al., 1988).

A current line of research is the relationship between core body temperature (CORE TEMP) and neurotoxicity engendered by MDMA and other amphetamines. Nash et al. (1988) first reported that MDMA-treated rats became hyperthermic. It was shown later that prevention of MDMA-induced hyperthermia prevents neurotoxicity, and that many drugs that protect against MDMA-induced neurotoxicity lower the CORE TEMP of the animals (Farfel and Seiden, 1995a; Malberg et al., 1996). Farfel et al. (1995b) have correlated protection against MDMA- and methamphetamine (METH)-induced neurotoxicity with a decrease in CORE TEMP, indicating that cooling of the body and

Received Jan. 5, 1998; revised April 13, 1998; accepted April 15, 1998.

This work was supported by National Institute on Drug Abuse Grant DA00085. L.S.S. was supported by Research Scientist Award MH-105-62. We thank Georgetta Vosmer for technical assistance and advice.

Correspondence should be addressed to Dr. Lewis S. Seiden, University of Chicago, 947 East 58th Street, Department of Pharmacological and Physiological Sciences, Abbott 109, Chicago, IL 60637.

Copyright (C) 1998 Society for Neuroscience $\quad 0270-6474 / 98 / 185086-09 \$ 05.00 / 0$ prevention of MDMA- or METH-induced hyperthermia prevents neurotoxicity.

The ambient temperature (AMB TEMP) during MDMA or METH administration also affects CORE TEMP and neurotoxicity (Ali et al., 1994; Miller and O’Callaghan, 1994). A cold AMB TEMP produces hypothermia in both MDMA- and METH-treated rats and protects against MDMA- and METHinduced neurotoxicity (Bowyer et al., 1993, 1994). The converse also occurs; administration of MDMA in a warm environment increases CORE TEMP (Gordon et al., 1991), and METHtreated rats show increased neurotoxicity at higher AMB TEMPs (Bowyer et al., 1994).

This increase or decrease in CORE TEMP as determined by AMB TEMP indicates that MDMA may compromise thermoregulatory ability, i.e., the ability to maintain a normal CORE TEMP. This is of clinical interest because lethalities or complications caused by MDMA are often accompanied by hyperthermia (Henry, 1992; McCann et al., 1996). Because MDMA is often taken at "rave parties," where dancing takes place in a warm environment (Green et al., 1995), this strongly suggests that the affect of MDMA on thermoregulation extends to humans in these circumstances (McCann et al., 1996).

To date, no precise study of the interaction between temperature and MDMA-induced neurotoxicity has been performed. Two major difficulties in performing these studies are the precise control of AMB TEMP and noninvasive measurement of CORE TEMP, because handling the rats can affect core temperature up to $1^{\circ} \mathrm{C}$ (Gordon, 1993). To address these problems, we developed a novel temperature measurement apparatus that (1) maintains 
AMB TEMP $\pm 0.5^{\circ} \mathrm{C}$ and (2) measures CORE TEMP once per minute using a noninvasive technique.

The purpose of this study was to investigate the interaction of AMB TEMP, CORE TEMP, and MDMA-induced 5-HT neurotoxicity. Twenty or $40 \mathrm{mg} / \mathrm{kg}$ MDMA was administered to rats in controlled AMB TEMPs of $20,22,24,26,28$, and $30^{\circ} \mathrm{C} ; 2$ weeks later, regional brain 5-HT and 5-HIAA levels were analyzed to assess neurotoxicity. A preliminary presentation of this work has been made in abstract form (Malberg and Seiden, 1996).

\section{MATERIALS AND METHODS}

\section{Animals}

One hundred forty-six male Holtzman (Madison, WI) rats were used, each weighing $\sim 250-300 \mathrm{gm}$ at time of injection. Rats were grouphoused (four to five per cage) in plastic cages with a room temperature of $22-24^{\circ} \mathrm{C}$, except on the drug injection days, when they were housed individually in the temperature measurement apparatus at different AMB TEMPs (see Temperature measurement apparatus and Experimental procedure below). Throughout the experiment, rats had access to food (Teklab Diet) and water ad libitum and were maintained on a $12 \mathrm{hr}$ light/dark cycle. Housing and experimental treatment of the rats were in accordance with National Institutes of Health guidelines.

\section{Drugs}

( \pm )-3,4-Methylenedioxymethamphetamine $\mathrm{HCl}$ was obtained from the National Institute on Drug Abuse. Ketamine and xylazine were obtained from Abbott Labs (Chicago, IL). All chemicals used were of analytical grade. Drug dosages are expressed as the weight of the salt, and drugs were dissolved in $0.9 \% \mathrm{NaCl}$.

\section{Temperature measurement apparatus}

A novel temperature measurement chamber was developed. This consists of an arrangement of components (computer, computer interface cards, AMB TEMP and CORE TEMP temperature sensors, housing chamber, and Visual Basic software) that forms an integrated system to perform the following functions: (1) measure and maintain a constant $\mathrm{AMB}$ TEMP (any temperature from 5 to $45^{\circ} \mathrm{C}, \pm 0.5^{\circ} \mathrm{C}$ ) using a feedback system that monitors AMB TEMP on a minute-to-minute basis; and (2) measure CORE TEMP once per minute in freely moving animals.

The temperature chambers are modified refrigerators $(0.20$ cubic meters) that have a 1-inch-thick Plexiglas window in the door to allow observation of the rats and to keep the light/dark cycle in synchrony with rat housing light sources. The rat is unrestrained and allowed to move freely within a cage $(20.3 \mathrm{~cm}$ wide, $15.2 \mathrm{~cm}$ high, and $16.5 \mathrm{~cm}$ deep) inside the chamber. The cage is large enough to allow the rat to circle, rear, and show exploratory locomotion. The cage has a hardware cloth $(1.3 \mathrm{~cm}$ mesh) floor, top, and back wall to ensure air flow within the cage and has a Plexiglas door and side walls. Each refrigerator has been modified so that in addition to a compressor to cool the chamber, there is also a strip heater and a fan to ensure that the AMB TEMP is even throughout the chamber. A thermistor to record AMB TEMP is mounted in the chamber $10.2 \mathrm{~cm}$ from the rat cage. To measure CORE TEMP, a temperature-sensitive transmitter (Minimitter Co., Sunriver, OR) that emits an AM radio signal proportional to the CORE TEMP of the rat is implanted in the peritoneal cavity of the rat. Four AM radios (Radio Shack) surrounding the outside of the rat cage receive signals from the transmitter.

The heating and cooling elements, thermistor, and CORE TEMP radio receivers are interfaced to a standard microcomputer $(33 \mathrm{MHz}$, 386 DX), which has an analog-to-digital interface allowing the environmental and CORE TEMPs to be recorded. Both CORE TEMP and AMB TEMP readings are recorded once per second and then averaged to produce one reading per minute.

The computer also has digital output lines that turn the compressor or heater off and on inside the chamber. To maintain AMB TEMP, the heating or cooling is turned on or off as necessary to maintain the desired $\mathrm{AMB}$ TEMP $\pm 0.5^{\circ} \mathrm{C}$. This monitoring of AMB TEMP is done every minute. In addition to monitoring AMB TEMP, the software can also be programmed to prevent the rat from reaching lethal hyperthermia. If the rat CORE TEMP increases over a certain temperature point (set by the experimenter), the AMB TEMP decreases until the rat CORE TEMP drops below that point. The entire system is run by a novel Visual Basic computer program. Eight temperature chambers are used and run independently of each other, allowing up to eight different experiments to be run at the same time.

The use of minimitters to measure rat CORE TEMP has been demonstrated as valid and reliable (Dilsaver et al., 1992). The minimitters have a resolution of $\pm 0.01^{\circ} \mathrm{C}$ (Clement et al., 1989).

\section{Surgery}

To implant the CORE TEMP transmitters, rats were anesthetized with ketamine $(0.6 \mathrm{mg} / \mathrm{ml} ; 1 \mathrm{ml} / \mathrm{kg})$ and xylazine $(100 \mathrm{mg} / \mathrm{ml} ; 0.33 \mathrm{ml} / \mathrm{kg})$ and were given supplemental $1 \mathrm{ml}$ injections of ketamine as needed. A midline cut was made in the peritoneum, and a sterilized transmitter was inserted into the peritoneal cavity, as described by Farfel and Seiden (1995a). Rats were allowed a minimum of $3 \mathrm{~d}$ to recover from the surgeries before drug injections.

\section{Experimental procedure}

Parametric experiment: effect of different AMB TEMPs on CORE TEMP and neurotoxicity. At 9:00 A.M., rats were placed in the temperature measurement chamber at an AMB TEMP of $24^{\circ} \mathrm{C}$ (the usual AMB TEMP in the laboratory) for a baseline CORE TEMP measurement and to prevent any hyperthermia induced by exploratory locomotion from interfering with the effects of the drug. After $1 \mathrm{hr}$, the AMB TEMP was set at one of the following: $20,22,24,26,28$, or $30^{\circ} \mathrm{C}$. Once the chamber reached the desired AMB TEMP, rats were given a subcutaneous injection of MDMA $(20 \mathrm{or} 40 \mathrm{mg} / \mathrm{kg})$ or saline (SAL; $1 \mathrm{ml} / \mathrm{kg})$. The rats remained at that AMB TEMP for $24 \mathrm{hr}$ after the injection. After $24 \mathrm{hr}$, the rats were returned to their group-housing conditions. Two weeks after the injection, the rats were killed by decapitation, and the following regions were dissected, as described by Sabol et al. (1996): frontal cortex, somatosensory cortex, hippocampus, and striatum. Tissue sections were stored in liquid nitrogen until ready for neurochemical analysis.

Heating experiment: effect of hyperthermia on neurotoxicity. In a separate experiment to investigate the effect of hyperthermia on 5-HT, 5-HIAA, dopamine (DA), homovanillic acid (HVA), dihydroxyphenyl acetic acid (DOPAC), and norepinephrine (NE) levels, saline-treated rats were placed in the temperature chamber at $24^{\circ} \mathrm{C}$ for $1 \mathrm{hr}$ to establish a baseline CORE TEMP. The AMB TEMP was then either increased to $40^{\circ} \mathrm{C}$ or remained at $24^{\circ} \mathrm{C}$. The rats remained at that AMB TEMP $(24$ or $40^{\circ} \mathrm{C}$ ) for $8 \mathrm{hr}$. For rats exposed to $40^{\circ} \mathrm{C}$ AMB TEMP, we prevented lethality by keeping the rat CORE TEMP at $\leq 41^{\circ} \mathrm{C}$. This maximum CORE TEMP was chosen because it has been reported that a CORE TEMP over $41.3^{\circ} \mathrm{C}$ in amphetamine-treated rats produces lethal hyperthermia and heatstroke (Bowyer et al., 1994). To keep rat CORE TEMP at $\leq 41^{\circ} \mathrm{C}$, the AMB TEMP was kept at $40^{\circ} \mathrm{C}$ unless the rat CORE TEMP exceeded $41^{\circ} \mathrm{C}$. At that point, the AMB TEMP was automatically decreased until the rat CORE TEMP was $<41^{\circ} \mathrm{C}$. When the rat was $<41^{\circ} \mathrm{C}$ CORE TEMP, the AMB TEMP was again increased to $40^{\circ} \mathrm{C}$. Two weeks after this treatment, rats were killed by decapitation, and the frontal cortex and somatosensory cortex were dissected as described above.

\section{Neurochemical assays}

5-HT, 5-HIAA, DA, HVA, DOPAC, and NE in the various rat brain regions were assayed by HPLC with electrochemical detection (HPLCEC) according to the method of Sabol et al. (1996) and Kotake (1985).

\section{Core temperature analysis}

The CORE TEMP data were quantified by using an area under the curve analysis. For each rat, a CORE TEMP versus time graph was generated, and the area between each CORE TEMP versus time curve and $y=0$ was calculated using a trapezoidal area under the curve analysis. In this way, the CORE TEMP response of each rat could be quantified and assigned a number value so that the CORE TEMP data could be analyzed using inferential statistics. This area under the curve value was denoted as the "total CORE TEMP" response for each rat. The CORE TEMP responses for all rats in each experimental group $(n=8)$ were summed together so that statistical analysis could be performed. This area under the curve value more accurately reflects the CORE TEMP changes over time for all the groups as opposed to using the mean CORE TEMP for each group (Clement et al., 1989; Dilsaver et al., 1990).

\section{Statistics}

For neurotoxicity data, differences were determined by ANOVA followed by a Tukey post hoc test (Instat for Macintosh computers, Graph- 


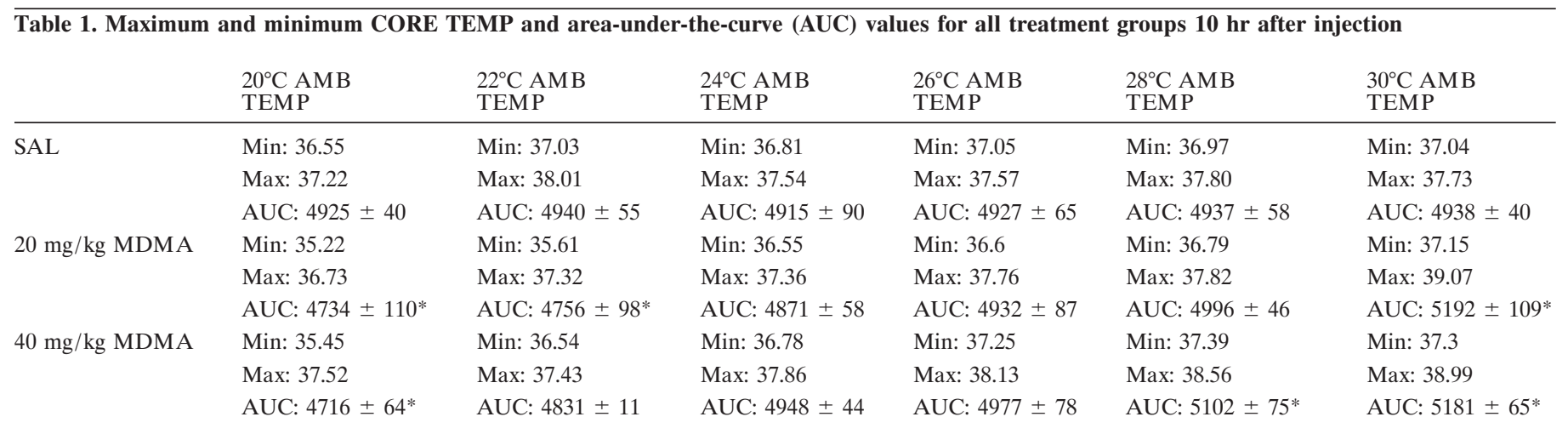

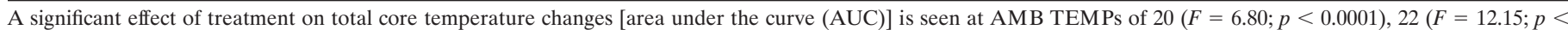

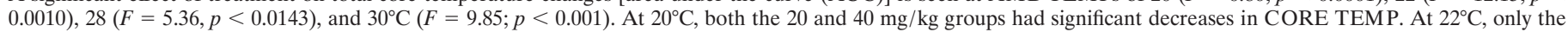

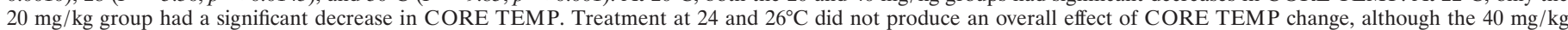

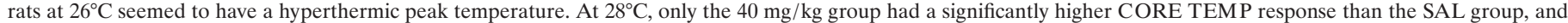
at $30^{\circ} \mathrm{C}$, both the 20 and $40 \mathrm{mg} / \mathrm{kg}$ groups had significantly higher CORE TEMP response.

${ }^{*} p<0.01$ Total CORE TEMP change, as measured by the AUC compared with SAL group at that AMB TEMP.

Pad). For the CORE TEMP analysis, two-way ANOVA for repeated measures was used to compare treatment groups (SuperAnova). Singletime point comparisons between groups were made using a Tukey post hoc test. Statistical significance was considered to be $p<0.05$ unless indicated otherwise.

\section{RESULTS}

\section{Parametric experiment: effects of MDMA and different AMB TEMPs on rat CORE TEMP}

Each rat was given SAL or MDMA ( 20 or $40 \mathrm{mg} / \mathrm{kg}$ ) at one of six different AMB TEMPs of 20, 22, 24, 26, 28, or $30^{\circ} \mathrm{C}$. For all rats, a $1 \mathrm{hr}$ baseline CORE TEMP was recorded. In that time, the average CORE TEMP was $37.8 \pm 0.05^{\circ} \mathrm{C}$. After the baseline hour the AMB TEMP was adjusted, and animals were injected with MDMA or SAL in the different AMB TEMPs.

There were no effects on CORE TEMP in any of the SALtreated rats at any of the six different AMB TEMPs. The average CORE TEMP for all SAL-treated rats $(n=48)$ was $37.3 \pm$ $0.07^{\circ} \mathrm{C}$ for the entire $24 \mathrm{hr}$ spent in the temperature measurement apparatus. This indicates that AMB TEMPs of $20-30^{\circ} \mathrm{C}$ do not affect the CORE TEMP of SAL-treated animals. In contrast, MDMA-treated animals had a markedly different CORE TEMP profile in different AMB TEMPs. MDMA administration in AMB TEMPs of 20 and $22^{\circ} \mathrm{C}$ produced a hypothermia compared with SAL controls. MDMA administration in AMB TEMPs of $28-30^{\circ} \mathrm{C}$ produced a hyperthermia compared with SAL controls (Table 1; Fig. $1 A-F$ ). Both SAL- and MDMA-treated rats returned to a CORE TEMP of $37.5 \pm 0.01^{\circ} \mathrm{C}$ by $11 \mathrm{hr}(660 \mathrm{~min})$ after the MDMA was injected. For this reason, all figures and statistical analysis of the CORE TEMP results include only the first $11 \mathrm{hr}$ of the experiment.

The effects of incrementally higher AMB TEMPs on CORE TEMPs can be readily seen for each dose (Fig. $2 A, B$ ). Taken together, these data indicate that small $\left(2^{\circ} \mathrm{C}\right)$ changes in $\mathrm{AMB}$ TEMP affect the CORE TEMP of the rat and that the ability of the rats to thermoregulate is impaired when given 20 or $40 \mathrm{mg} / \mathrm{kg}$ MDMA.

\section{Effects of different AMB TEMPs on MDMA-induced 5-HT neurotoxicity}

The effect of different AMB TEMPs on MDMA-induced neurotoxicity is shown in Figures 3 and 4. In this experiment, decreases in 5-HT and 5-HIAA levels were measured as indicators of neurotoxicity; we have found this to be a reliable marker of MDMA neurotoxicity (Lew et al., 1996; Sabol et al., 1996).

There were no significant depletions of 5-HT at AMB TEMPs of 20,22 , or $24^{\circ} \mathrm{C}$ in any of the brain regions examined. As AMB TEMP increased above $24^{\circ} \mathrm{C}$, significant depletions were seen, with higher AMB TEMPs inducing greater depletions. At $26^{\circ} \mathrm{C}$, there were significant depletions of 5-HT compared with control in the frontal cortex (87\% of control) $(p<0.05$ for all post hoc tests), hippocampus (80\%), and striatum $(72 \%)$ in the $40 \mathrm{mg} / \mathrm{kg}$ group and in the somatosensory cortex in both the 20 and 40 $\mathrm{mg} / \mathrm{kg}$ groups ( 90 and $82 \%$, respectively) (see Figures 3 and 4 for $F$ values).

At $28^{\circ} \mathrm{C}$, there were significant 5-HT depletions compared with control in the frontal cortex (75\% of control) in the $40 \mathrm{mg} / \mathrm{kg}$ group. All other regions had depletions in both the 20 and 40 $\mathrm{mg} / \mathrm{kg}$ group: somatosensory cortex, 80 and $66 \%$, respectively; hippocampus, 75 and $65 \%$, respectively; and striatum, 71 and $61 \%$, respectively.

At $30^{\circ} \mathrm{C}$, both the $20 \mathrm{~kg}$ and $40 \mathrm{mg} / \mathrm{kg}$ MDMA-treated groups had decreases in 5-HT levels compared with control in all regions examined: somatosensory cortex, 70 and $65 \%$, respectively; hippocampus, 58 and $42 \%$, respectively; frontal cortex, 63 and $70 \%$, respectively; and striatum, 74 and $66 \%$, respectively.

The 5-HIAA level data were very similar to the 5-HT levels data; treatment at 20 and $22^{\circ} \mathrm{C}$ AMB TEMP produced no changes in 5-HIAA levels, and higher AMB TEMPs produced decreases in 5-HIAA levels. The one difference was that at $24^{\circ} \mathrm{C}$, 5-HIAA levels were affected, whereas 5-HT levels were not affected until the AMB TEMP reached $26^{\circ} \mathrm{C}$. At $24^{\circ} \mathrm{C}$ AMB TEMP, there was a significant decrease in 5-HIAA levels compared with control in the $40 \mathrm{mg} / \mathrm{kg}$ group in the frontal cortex (72.7\% of control), somatosensory cortex (77\%), and hippocampus $(79 \%)$.

At $26^{\circ} \mathrm{C}$ AMB TEMP, the $40 \mathrm{mg} / \mathrm{kg}$ group showed significant depletions compared with 5-HIAA depletions to control in the frontal cortex (70\% of control), hippocampus (79\%), and striatum $(64 \%)$.

Treatment at $28^{\circ} \mathrm{C}$ AMB TEMP produced decreases in 5 -HIAA levels compared with control in the $40 \mathrm{mg} / \mathrm{kg}$ group in all regions: somatosensory cortex, $69 \%$ of control; hippocampus, $72 \%$; frontal cortex, $70 \%$; and striatum, $64 \%$. 
A AMBIENT TEMPERATURE $20 \mathrm{C}$

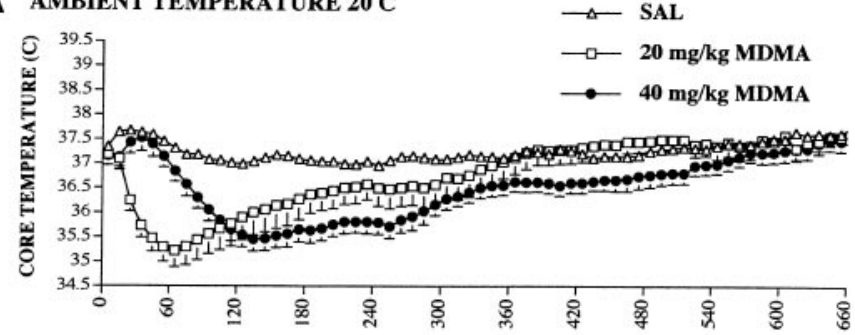

B AMBIENT TEMPERATURE 22 C

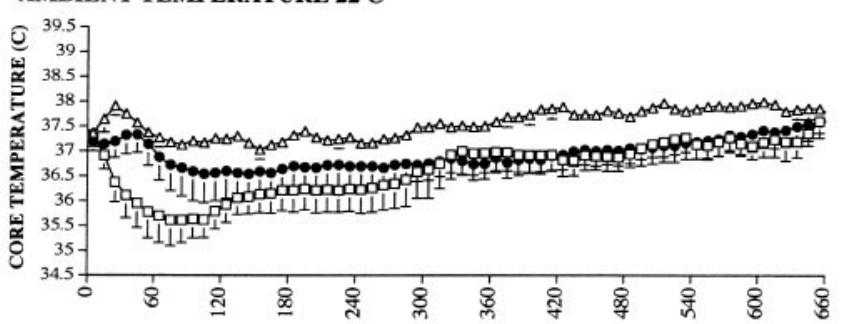

C AMBIENT TEMPERATURE $24 \mathrm{C}$

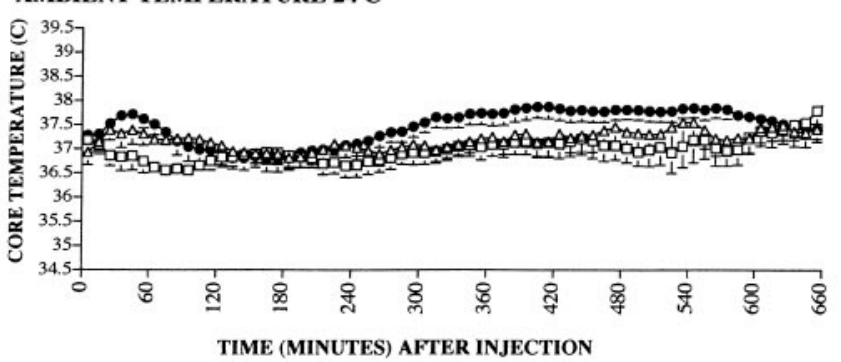

D AMBIENT TEMPERATURE $26 \mathrm{C}$

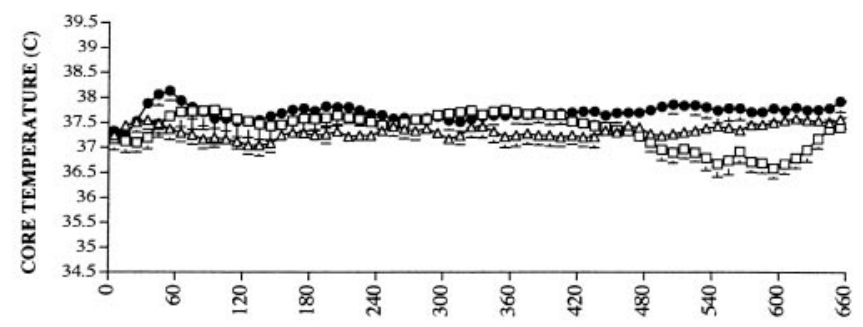

E AMBIENT TEMPERATURE $28 \mathrm{C}$

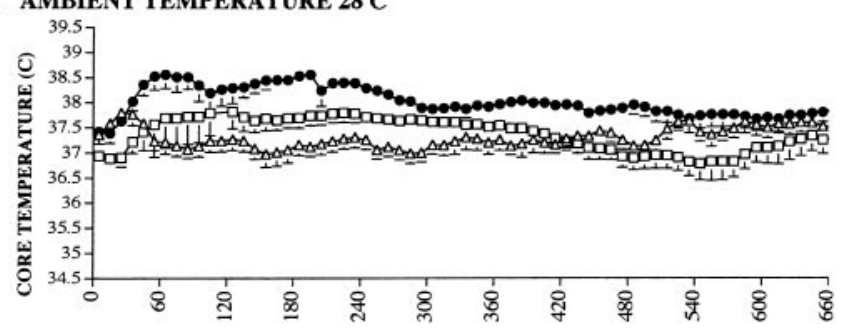

F AMBIENT TEMPERATURE $30 \mathrm{C}$

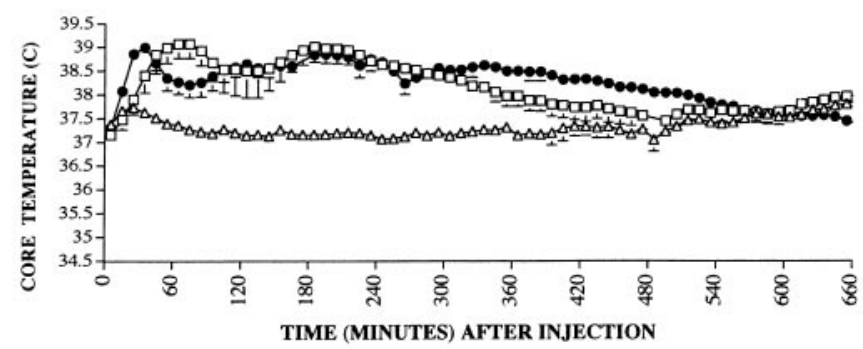

Figure 1. CORE TEMP versus time responses for rats treated at AMB TEMP of $20(A), 22(B), 24(C), 26(D), 28(E)$, and $30^{\circ} \mathrm{C}(F)$ for 660 min $(11 \mathrm{hr})$ after injection. All rats were injected at time 0 with $1 \mathrm{ml} / \mathrm{kg} \mathrm{SAL}, 20 \mathrm{mg} / \mathrm{kg}$ MDMA, or $40 \mathrm{mg} / \mathrm{kg}$ MDMA at the indicated AMB TEMP. Rats were placed in the temperature-controlled chamber for $1 \mathrm{hr}$ before injection for baseline measurements. $n=8$ for all experimental groups. All values are mean \pm SEM.

At $30^{\circ} \mathrm{C}$ AMB TEMP, both the 20 and $40 \mathrm{mg} / \mathrm{kg}$ MDMAtreated groups had significant decreases in 5-HIAA levels in all regions: somatosensory cortex, 70 and 73\%, respectively; hippocampus, 58 and $56 \%$, respectively; frontal cortex, 63 and $60 \%$, respectively; and striatum, 54 and $70 \%$, respectively.

These results clearly indicate that at $20-24^{\circ} \mathrm{C}$, there is protection against MDMA-induced decreases in 5-HT levels, and at $20-22^{\circ} \mathrm{C}$ there is protection against 5-HIAA decreases. At 26$28^{\circ} \mathrm{C}$ there is increased neurotoxicity, and by $28-30^{\circ} \mathrm{C}$ all treatment groups are significantly affected. These results point to a large effect of AMB TEMP in determination of MDMA-induced neurotoxicity.

\section{Correlation between AMB TEMP and neurotoxicity}

Regression analysis was used to determine a correlation between the area under the curve and neurotoxicity (decrease in 5-HT and 5-HIAA levels) in all MDMA-treated animals. All regions had significant negative correlations (Table 2) for both 5-HT and 5-HIAA levels. These data indicate that as the CORE TEMP of animals treated with MDMA increases above a normal CORE TEMP, 5-HT and 5-HIAA levels decrease.

\section{Lethality}

In the parametric experiment, lethality was not prevented as it was in the heating experiment so that the percentage of lethality for each AMB TEMP-dose combination could be determined. In the $40 \mathrm{mg} / \mathrm{kg} 30^{\circ} \mathrm{C} \mathrm{AMB} \mathrm{TEMP} \mathrm{group,} \mathrm{we} \mathrm{obtained} 20 \%$ lethal- ity. This is less lethality than Gordon et al. (1991) obtained at the same AMB TEMP. This may be attributable to the fact that in our temperature measurement chamber, there was a constant movement of air because of the fan, so that any lethality attributable to additional humidity was attenuated in our temperature chamber.

\section{Effect of hyperthermia on SAL-treated rats}

Saline-treated rats in an AMB TEMP of $24^{\circ} \mathrm{C}$ had an average CORE TEMP of $37.4 \pm 0.02^{\circ} \mathrm{C}$, and saline-treated rats treated at an AMB TEMP of $40^{\circ} \mathrm{C}$ had an average CORE TEMP of $39 \pm$ $0.08^{\circ} \mathrm{C}$, with a peak CORE TEMP of $40.89^{\circ} \mathrm{C}$. There was a significant difference $(p<0.0001)$ in CORE TEMP response between the rats treated at 24 and $40^{\circ} \mathrm{C}$, indicating that an $\mathrm{AMB}$ TEMP of $40^{\circ} \mathrm{C}$ produces hyperthermia in SAL-treated rats. Twenty-four hours after the rats were placed in the temperature measurement apparatus, all rats had average CORE TEMPs of $37.5 \pm 0.03^{\circ} \mathrm{C}$.

There was no change in any neurotransmitter level (5-HT, 5-HIAA, DA, DOPAC, HVA, and NE) between the rats treated at 24 and $40^{\circ} \mathrm{C} \mathrm{AMB} \mathrm{TEMP} \mathrm{in} \mathrm{all} \mathrm{of} \mathrm{the} \mathrm{brain} \mathrm{regions} \mathrm{examined.}$ In the interest of space, only the frontal cortex and somatosensory cortex data are shown (Fig. $5 A, B$ ). This indicates that the significant CORE TEMP hyperthermia induced by a $40^{\circ} \mathrm{C}$ AMB TEMP causes no changes in neurotransmitter levels. This is in 
A

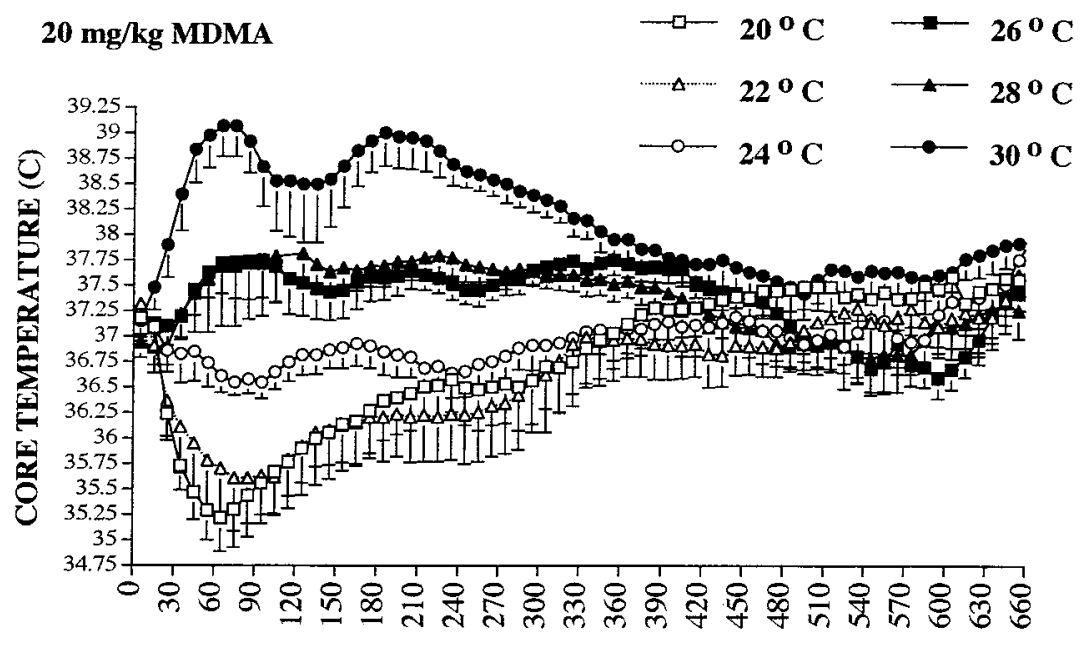

B

Figure 2. Summary of CORE TEMP versus time responses for all rats treated with either $20 \mathrm{mg} / \mathrm{kg}$ MDMA $(A)$ or $40 \mathrm{mg} / \mathrm{kg}$ MDMA $(B)$ at different AMB TEMPs $\left(20,22,24,26,28\right.$, and $\left.30^{\circ} \mathrm{C}\right)$.

agreement with Wilkinson et al. (1991), who looked at pyrogeninduced fever on 5-HT levels and found no significant effect.

This control experiment demonstrates that the changes in neurotransmitter levels seen in our MDMA experiment are not attributable to the CORE TEMP hyperthermia alone but are attributable to the CORE TEMP hyperthermia interacting with the MDMA. The hyperthermia itself does not cause depletions in neurotransmitter levels.

\section{DISCUSSION}

The main finding of this study is that a small $\left(2^{\circ} \mathrm{C}\right)$ change in AMB TEMP produces marked changes in both CORE TEMP and MDMA-induced 5-HT neurotoxicity. Although previous studies (Gordon et al., 1991; Bowyer et al., 1994; Miller and O'Callaghan, 1994) have demonstrated that large changes in AMB TEMP affect CORE TEMP and neurotoxicity, the present study is the first to investigate the effect of small controlled changes in AMB TEMP. We demonstrate that MDMA disrupts thermoregulatory ability, and this in turn makes the CORE TEMP dependent on the AMB TEMP. The resulting changes in CORE TEMP affect MDMA-induced neurotoxicity. This study underscores the importance of a constant and controlled AMB TEMP in any experimental paradigm investigating MDMA neurotoxicity.

It can be seen that above $24^{\circ} \mathrm{C}$ degrees AMB TEMP, changes in AMB TEMP increase the neurotoxicity. We hypothesize that there is a critical AMB TEMP, which we term "break point," below which protection is seen. Increases in AMB TEMP from this point increase MDMA-induced neurotoxicity. The break point for a single dose of 20 or $40 \mathrm{mg} / \mathrm{kg}$ MDMA seems to be $24^{\circ} \mathrm{C}$, although most likely this break point is different for other MDMA doses and amphetamine analogs and may differ in different-sized animals and species.

It is of interest that at $24^{\circ} \mathrm{C}$ AMB TEMP, 5-HIAA levels are decreased, whereas 5-HT levels are not affected until $26^{\circ} \mathrm{C}$ AMB TEMP. It may be that the decrease in 5-HIAA levels near the break point is indicative of partial damage to cellular metabolism, although further research is needed to determine its extent and characterization.

MDMA and other amphetamines have been shown to disrupt thermoregulation in both rats and humans (Gordon et al., 1991; 
HIPPOCAMPUS

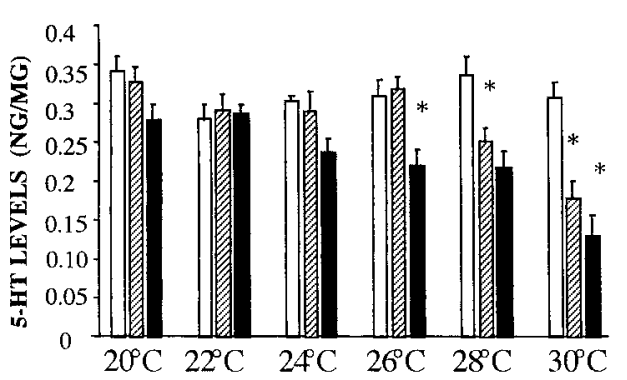

STRIATUM

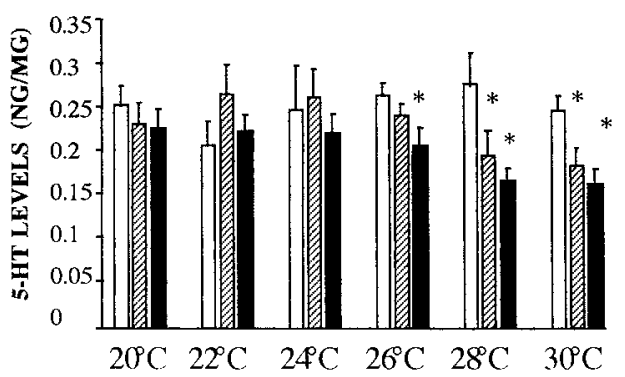

AMBIENT TEMPERATURE

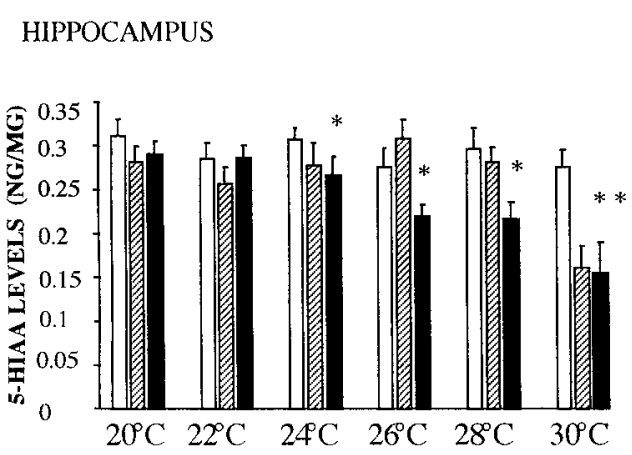

STRIATUM

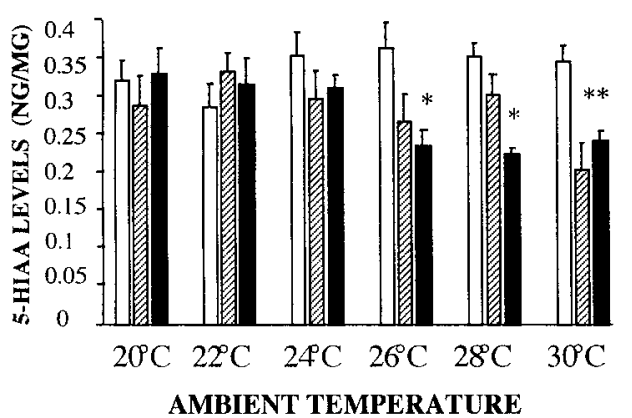

$\begin{array}{lll}\text { FRONTAL CORTEX } & \square & \text { SAL } \\ 20 \mathrm{mg} / \mathrm{kg} \text { MDMA } \\ 40 \mathrm{mg} / \mathrm{kg} \text { MDMA }\end{array}$

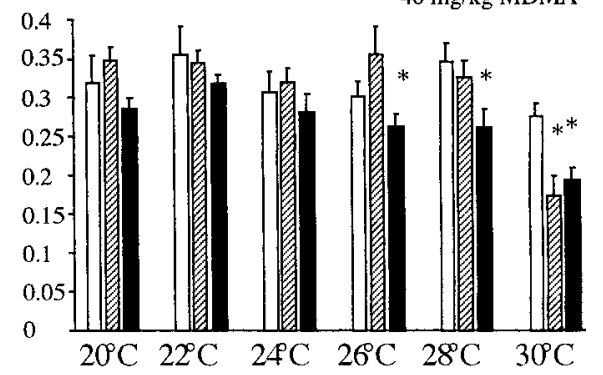

SOMATOSENSORY CORTEX

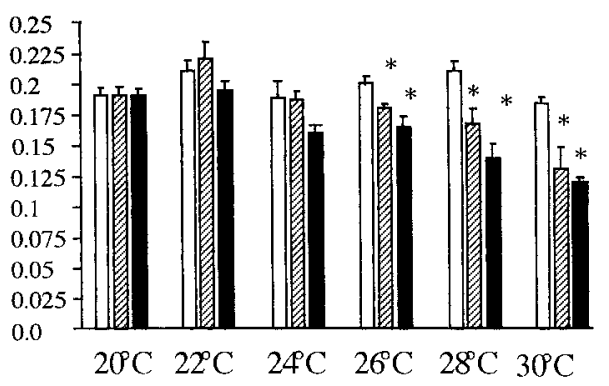

AMBIENT TEMPERATURE
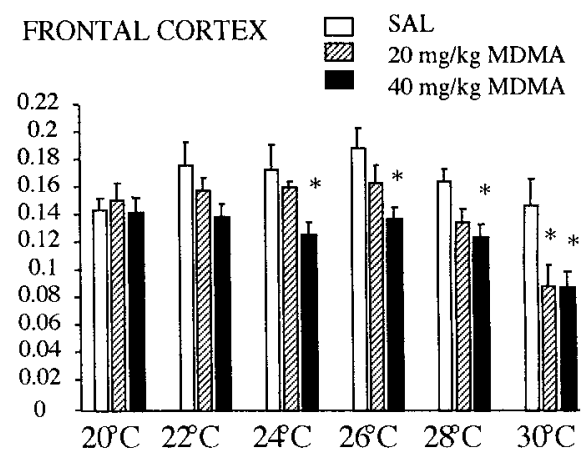

SOMATOSENSORY CORTEX

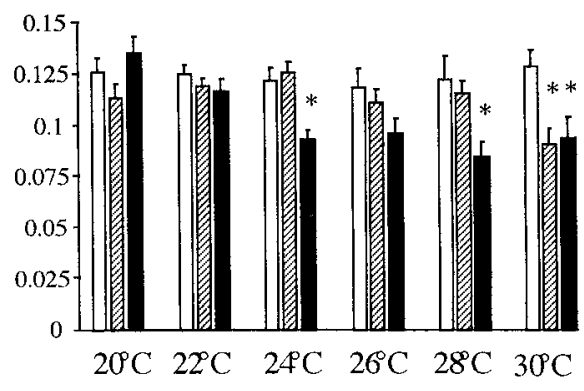

AMBIENT TEMPERATURE
Figure 3. 5-HT levels from all experimental groups 2 weeks after MDMA or SAL injections. ${ }^{*} p<0.05$ compared with the SAL group at that AMB TEMP. All tissue weights are expressed in nanograms per milligrams of wet tissue weight. $n=8$ for all experimental groups. All values are mean \pm SEM. In the hippocampus, a significant effect of treatment was obtained at $\mathrm{AMB}$ TEMPs of $26^{\circ} \mathrm{C}(F=6.09 ; p<0.01), 28^{\circ} \mathrm{C}$ $(F=11.32 ; p<0.005)$, and $30^{\circ} \mathrm{C}(F=31.13$; $p<0.001)$. In somatosensory cortex, a significant effect of treatment was obtained at AMB TEMPs of $26^{\circ} \mathrm{C}(F=8.46 ; p<$ $0.005), 28^{\circ} \mathrm{C}(F=8.80 ; p<0.01)$, and $30^{\circ} \mathrm{C}$ $(F=9.37 ; p<0.01)$. In frontal cortex, a significant effect of treatment was obtained at AMB TEMPs of $26^{\circ} \mathrm{C}(F=4.23 ; p<$ $0.05), 28^{\circ} \mathrm{C}(F=3.95 ; p<0.05)$, and $30^{\circ} \mathrm{C}$ $(F=8.77 ; p<0.05)$. In striatum, a significant effect of treatment was obtained at $26^{\circ} \mathrm{C}(F=6.02 ; p<0.05), 28^{\circ} \mathrm{C}(F=4.45$; $p<0.02)$, and $30^{\circ} \mathrm{C}(F=4.75 ; p<0.05)$. See Results for percentage of depletions compared with control at each AMB TEMP.

Figure 4. 5-HIAA levels from all experimental groups 2 weeks after MDMA or SAL injections. ${ }^{*} p<0.05$ compared with the SAL group at that AMB TEMP. All tissue weights are expressed in nanograms per milligram of wet tissue weight. $n=8$ for all experimental groups. All values are mean \pm SEM. In the hippocampus, a significant effect of treatment was obtained at AMB TEMPs of $24^{\circ} \mathrm{C}(F=3.70 ; p<0.05), 26^{\circ} \mathrm{C}(F=6.47$; $p<0.01), 28^{\circ} \mathrm{C}(F=4.86 ; p<0.05)$, and $30^{\circ} \mathrm{C}(F=7.80 ; p<0.005)$. In somatosensory cortex, a significant effect of treatment was obtained at AMB TEMPs of $24^{\circ} \mathrm{C}(F=9.81$; $p<0.005), 28^{\circ} \mathrm{C}(F=4.67 ; p<0.05)$, and $30^{\circ} \mathrm{C}(F=5.32 ; p<0.05)$. In frontal cortex, a significant effect of treatment was obtained at AMB TEMPs $24^{\circ} \mathrm{C}(F=6.52 ; p<0.01)$, $26^{\circ} \mathrm{C}(F=5.34 ; p<0.05), 28^{\circ} \mathrm{C}(F=6.91 ;$ $p<0.01)$, and $30^{\circ} \mathrm{C}(F=4.67 ; p<0.05)$. In striatum, a significant effect of treatment was obtained at $26^{\circ} \mathrm{C}(F=5.24 ; p<0.005), 28^{\circ} \mathrm{C}$ $(F=14.39 ; p<0.001)$, and $30^{\circ} \mathrm{C}(F=7.79$; $p<0.01)$. See Results for percentage of depletions compared with control at each AMB TEMP.
Dafters, 1995; McCann et al., 1996). The MDMA-induced loss of thermoregulation in rats has been shown to occur not only in neurotoxic doses (Gordon et al., 1991; Gordon and Fogelson, 1994) but also in non-neurotoxic doses (Dafters, 1994; Ainsworth et al., 1997). This has received much attention because of the number of MDMA-related fatalities that have involved hyperthermia and heatstroke (Henry, 1992; Dar and McBrien, 1996). Many, but not all, of these overdoses arise from MDMA use at rave parties (Green et al., 1995; McCann et al., 1996). The use of MDMA or other amphetamines combined with high AMB
TEMP seen at rave parties and hyperthermia induced by dancing (Sternbach, 1991) may all contribute to the hyperthermiaassociated problems with MDMA use.

The MDMA-induced hyperthermia has been theorized to be linked to the "serotonin syndrome" (Ames and Wirshing, 1993; Friedman, 1993). This syndrome consists of hyperthermia and other symptoms (Sternbach, 1991) and is thought to result from excess 5-HT at the 5-HT1 $1_{\mathrm{A}}$ receptor (Ames and Wirshing, 1993; Sporer, 1995). Given that MDMA induces 5-HT release, it has been theorized that there is a link between MDMA-induced 


\begin{tabular}{lll}
\hline $\begin{array}{l}\text { Table 2. Correlation of CORE TEMP response and 5-HT or } \\
\text { 5-HIAA levels }\end{array}$ & \\
& $R^{2}$ & $p$ \\
\hline Region & & \\
\hline Frontal cortex & 0.47 & $<0.002$ \\
$\quad$ 5-HT & 0.31 & $<0.017$ \\
5-HIAA & & \\
Hippocampus & 0.47 & $<0.002$ \\
5-HT & 0.39 & $<0.006$ \\
5-HIAA & & $<0.0001$ \\
Somatosensory cortex & 0.57 & $<0.007$ \\
5-HT & 0.38 & $<0.006$ \\
5-HIAA & & $<0.013$ \\
Striatum & 0.39 & \\
5-HT & 0.33 & \\
5-HIAA & &
\end{tabular}

Correlation of total CORE TEMP response (area under the curve value) and 5-HT or 5-HIAA levels for all regions. Group means were used for calculation of $R^{2}$ values.

hyperthermia and serotonin syndrome (Kaskey, 1992; Ames and Wirshing, 1993; Friedman, 1993). This has been supported by studies in the rat in which 5-HT syndrome behaviors such as forepaw treading, head weaving, and a low body posture were induced by MDMA administration (Spanos and Yamamoto, 1989; Colado et al., 1993). These behaviors increased in intensity and duration of response with increasing doses of MDMA (Spanos and Yamamoto, 1989).

Our study indicates that MDMA-induced hyperthermia leads to neurotoxicity. We hypothesize that once MDMA enters the neuron via the 5-HT transporter (Rudnick and Wall, 1992), the hyperthermia would then affect and possibly increase the rate of reactions leading to MDMA-induced neurotoxicity. In support of this, we (Malberg et al., 1996) have shown that if MDMA is prevented from entering the 5-HT neuron by fluoxetine pretreatment, the rats still display hyperthermia, although no neurotoxicity is seen. Under these circumstances, the hyperthermia may be from MDMA stimulating $5-\mathrm{HT}_{2 \mathrm{~A} / \mathrm{C}}$ receptors. DOI and $\mathrm{M}-\mathrm{CPP}$, selective agonists to $5-\mathrm{HT}_{2 \mathrm{~A} / \mathrm{C}}$ and $5-\mathrm{HT}_{2 \mathrm{C}}$ receptors, respectively, have been shown to produce a hyperthermia (MazzolaPomietto et al., 1997), and MDMA has been shown to act as an agonist to 5- $\mathrm{HT}_{2 \mathrm{~A}}$ and 5- $\mathrm{HT}_{2 \mathrm{C}}$ receptors (Nash et al., 1994). This $5-\mathrm{HT}_{2 \mathrm{~A} / \mathrm{C}}-$ mediated hyperthermia could contribute to the neurotoxicity observed.

In contrast to hyperthermia increasing reactions leading to neurotoxicity, hypothermia may also protect by decreasing the rate of reactions leading to MDMA-induced neurotoxicity. A cold AMB TEMP has been shown to protect against neurotoxicity (Bowyer et al., 1993; Ali et al., 1994; Che et al., 1995), and many drugs that protect against neurotoxicity do so by lowering the rats' CORE TEMP (Bowyer et al., 1994; Miller and O'Callaghan, 1994; Farfel and Seiden, 1995a,b; Malberg et al., 1996). Hypothermia has also been shown to be neuroprotective in other models of brain injury (Ginsberg et al., 1992). We hypothesize that hypothermia may slow down some of the reactions leading to METH-induced neurotoxicity. It is not currently known how the hypothermia is produced. In a cold AMB TEMP, the hypothermia may come from an MDMA-induced deficit in the thermoregulatory system that results in an inability to produce normal heat-conservation or heat-production responses, which would make an animal hypothermic. Further experiments
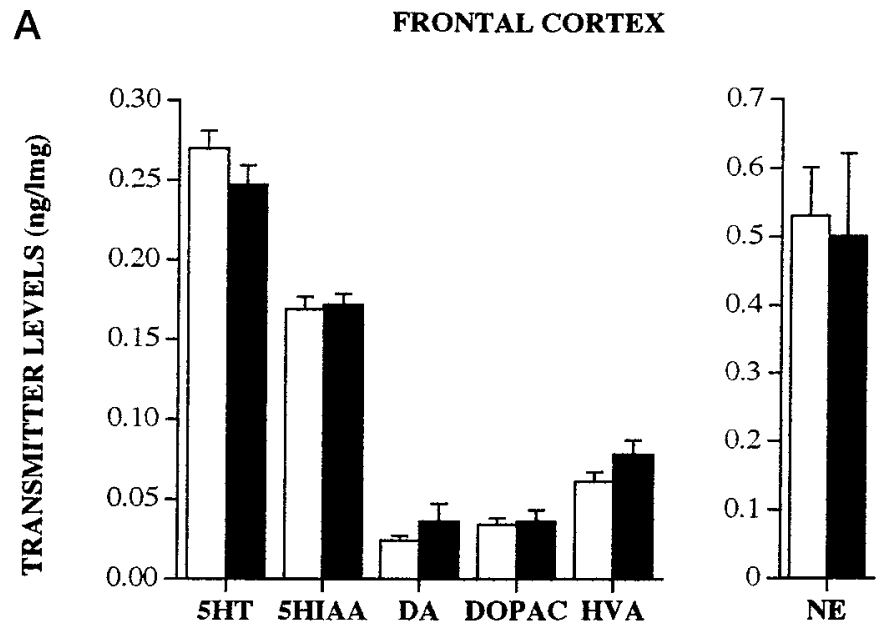

B SOMATOSENSORY CORTEX

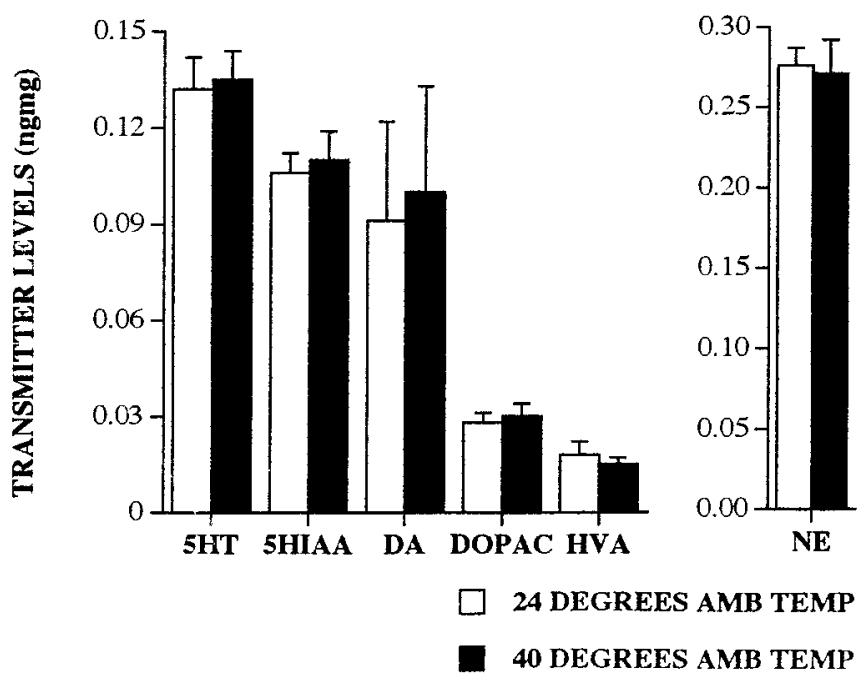

Figure 5. 5-HT, 5-HIAA, DA, DOPAC, HVA, and NE levels from SAL-treated rats exposed to an AMB TEMP of 24 or $40^{\circ} \mathrm{C}$ for $8 \mathrm{hr}$. Frontal cortex $(A)$ and somatosensory cortex levels $(B)$ were obtained 2 weeks after exposure. All tissue weights are expressed in nanograms per milligram of wet tissue weight. $n=8$ for all experimental groups. All values are mean \pm SEM.

are necessary to determine how and where MDMA would affect thermoregulatory responses.

There are several hypothesized mechanisms of neurotoxicity. For many of the reactions leading to neurotoxicity that have been experimentally investigated, hypothermia and hyperthermia may affect the rate of reactions. MDMA has been shown to bind to the 5-HT transporter (Rudnick and Wall, 1992). It is not known whether the CORE TEMP hypothermia or hyperthermia would affect in vivo binding of MDMA to the transporter. It has been shown, however, that plasma levels of MDMA are not affected by either a CORE TEMP hypothermia or hyperthermia (Colado et al., 1995) so that MDMA pharmacokinetics are not affected by changes in CORE TEMP.

Temperature has an affect on amphetamine-induced 5-HT and DA release, which may be important to neurotoxicity. Clausing et al. (1996) have shown using in vivo microdialysis that amphetamine-induced striatal DA levels correlate with maximum brain temperature, indicating that hyperthermia increases 
amphetamine-induced DA release. Conversely, Bowyer et al. (1992) have reported that a cold AMB TEMP, which lowers CORE TEMP, prevents METH-induced DA and 5-HT release. Changes in CORE TEMP, then, may affect the step of amphetamine-induced neurotransmitter release.

Free radical formation is hypothesized to be a major reaction leading to neurotoxicity (Halliwell, 1992; Cadet et al., 1994; Gudelsky, 1996). Therefore, the effect of CORE TEMP on the formation of free radicals may be a major point in preventing or increasing neurotoxicity. It has been shown that hypothermia prevents free radical formation; maintaining the brain at a hypothermic temperature prevents ischemia-induced 2,3- and 2,5dihydroxybenzoic acid formation. Conversely, free radical formation is increased in rats with hyperthermic brain temperature (Globus et al., 1995; Kil et al., 1996). These results show that formation of hydroxyl radicals in the brain is a temperaturedependent process. In addition, CORE TEMP hypothermia could decrease and hyperthermia could increase free radical formation such as 6-OHDA, 5,7-DHT, and NO (Halliwell, 1992). At least some, if not all, of these free radicals are theorized to participate in amphetamine-induced neurotoxicity (Seiden and Vosmer, 1984; Commins et al., 1987a; Dawson et al., 1993; Cadet et al., 1994).

Activation of excitatory amino acids and $\mathrm{Ca}^{2+}$ accumulation have been implicated in amphetamine-induced neurotoxicity (Sonsalla et al., 1989), and hypothermia may also prevent the accumulation of calcium ions. Hypothermia reduces glutamate and glycine release (Illievich et al., 1994) and $\mathrm{Ca}^{2+}$ accumulation and release (Corbett et al., 1990; Mitani et al., 1991), and this may contribute to hypothermic protection against neurotoxicity.

Kramer et al. $(1995,1997)$ have reported that MDMA induces translocation of the calcium- and phospholipid-dependent enzyme PKC and theorize that this prolonged kinase activation may contribute to the neurotoxicity. Interestingly, it has been reported that in hypothermic rats, ischemia-induced translocation of PKC was completely abolished (Cardell et al., 1991). This again points to hypothermia decreasing or preventing another neurotoxic reaction.

Another theory of neurotoxicity has been advanced by Carlsson (1993), who posits a feed-forward loop that is excited by amphetamines and causes continued release of neurotransmitter. This requires energy, and eventually the cell goes into ATP depletion and dies. Hypothermia may slow down this reaction; it has been shown that reduction of brain temperature significantly delays decreases in ATP throughout the hippocampus (Busto et al., 1987; Zeevalk and Nicklas, 1993). Therefore, hypothermic prevention of the ATP depletion may be another mechanism of protection against neurotoxicity.

In summary, this experiment used a novel temperature measurement apparatus to measure and control AMB TEMP and to measure CORE TEMP. We have shown that small $\left(2^{\circ} \mathrm{C}\right)$ changes in AMB TEMP have a large affect on CORE TEMP neurotoxicity in MDMA-treated animals. At low AMB TEMPs hypothermia and protection against neurotoxicity is seen, and at high AMB TEMPs we report a hyperthermia that correlates with increased neurotoxicity. This is in line with clinical evidence indicating reduced thermoregulation and lethality from MDMA use and 5-HT syndrome, and we offer a hypothesis that the hypothermia and hyperthermia may be acting on one or more of the reactions leading to neurotoxicity.

\section{REFERENCES}

Ainsworth AM, Malberg JE, Seiden LS (1997) High and low doses of 3,4-methylenedioxymethamphetamine (MDMA) impair thermoregulatory ability in the rat. Soc Neurosci Abstr 2:1352.

Ali SF, Newport GD, Holson RR, Slikker Jr W, Bowyer JF (1994) Low environmental temperatures or pharmacologic agents that produce hypothermia decrease methamphetamine neurotoxicity in mice. Brain Res 658:33-38.

Ames D, Wirshing WC (1993) Ecstasy, the serotonin syndrome, and neuroleptic malignant syndrome - a possible link [letter]? JAMA 269:869-870.

Battaglia G, Yeh SY, DeSouza EB (1988) MDMA-induced neurotoxicity: parameters of degeneration and recovery of brain serotonin neurons. Pharmacol Biochem Behav 29:269-274.

Bowyer JF, Tank AW, Newport GD, Slikker Jr W, Ali SF, Holson RR (1992) The influence of environmental temperature on the transient effects of methamphetamine on dopamine levels and dopamine release in rat striatum. J Pharmacol Exp Ther 260:817-824.

Bowyer JF, Gough B, Slikker Jr W, Lipe GW, Newport GD, Holson RR (1993) Effects of a cold environment or age on methamphetamineinduced dopamine release in the caudate putamen of female rats. Pharmacol Biochem Behav 44:87-98.

Bowyer JF, Davies DL, Schmued L, Broening HW, Newport GD, Slikker Jr W, Holson RR (1994) Further studies of the role of hyperthermia in methamphetamine neurotoxicity. J Pharmacol Exp Ther 268: 1571-1580.

Busto R, Dietrich WD, Globus MYT, Valdes I, Scheinberg P, Ginsberg MD (1987) Small differences in intraischmic brain temperature critically determine the extent of ischemic neuronal injury. J Cereb Blood Flow Metab 7:729-738.

Cadet JL, Ali S, Epstein C (1994) Involvement of oxygen-based radicals in methamphetamine-induced neurotoxicity: evidence from the use of CuZnSOD transgenic mice. Ann NY Acad Sci 738:388-391.

Cardell M, Boris-Moller F, Wieloch T (1991) Hypothermia prevents the ischemia-induced translocations and inhibition of protein kinase $\mathrm{C}$ in the rat striatum. J Neurochem 57:1814-1817.

Carlsson A (1993) Search for the neuronal circuitries and neurotransmitters involved in "positive" and "negative" schizophrenic symptomatology. Fidia Res Found Lect Ser 7.

Che S, Johnson M, Hanson GR, Gibb JW (1995) Body temperature effect on methylenedioxymethamphetamine-induced acute decrease in tryptophan hydroxylase activity. Eur J Pharmacol 293:447-453.

Clausing P, Bloom D, Newport GD, Holson RR, Slikker Jr W, Bowyer JF (1996) Individual differences in dopamine release but not rotational behavior correlate with extracellular amphetamine levels in caudate putamen in unlesioned rats. Psychopharmacology 127:187-194.

Clement JG, Mills P, Brockway B (1989) Use of telemetry to record body temperature and activity in mice. J Pharmacol Methods 21:129-140.

Colado MI, Murray TK, Green AR (1993) 5-HT loss in rat brain following 3,4-methylenedioxymethamphetamine (MDMA), pchloroamphetamine and fenfluramine administration and effects of chlormethiazole and dizocilpine. Br J Pharmacol 108:583-589.

Colado MI, Williams JL, Green AR (1995) The hyperthermic and neurotoxic effects of "Ecstasy" (MDMA) and 3,4 methylenedioxyamphetamine (MDA) in the Dark Agouti (DA) rat, a model of the CYP2D6 poor metabolizer phenotype. Br J Pharmacol 115:1281-1289.

Commins DL, Axt KJ, Vosmer G, Seiden LS (1987a) 5,6Dihydroxytryptamine, a serotonergic neurotoxin is formed endogenously in the rat brain. Brain Res 403:7-14.

Commins DL, Vosmer G, Virus RM, Woolverton WL, Schuster CR, Seiden LS (1987b) Biochemical and histological evidence that methylenedioxymethamphetamine (MDMA) is toxic to neurons in the rat brain. J Pharmacol Exp Ther 241:338-345.

Corbett D, Evans S, Thomas C, Wang D, Jonas RA (1990) MK-801 reduced cerebral ischemic injury by inducing hypothermia. Brain Res 514:300-304.

Dafters RI (1994) Effect of ambient temperature on hyperthermia and hyperkinesis induced by 3,4-methylenedioxymethamphetamine (MDMA or "ecstasy") in rats. Psychopharmacology 114:505-508.

Dafters RI (1995) Hyperthermia following MDMA administration in rats: effects of ambient temperature, water consumption and chronic dosing. Physiol Behav 58:877-882.

Dar KJ, McBrien ME (1996) MDMA induced hyperthermia: report of 
a fatality and review of current therapy. Intensive Care Med 22: 995-996.

Dawson VL, Dawson TM, Bartley DA, Uhl GR, Snyder SH (1993) Mechanisms of nitric oxide-mediated neurotoxicity in primary brain cultures. J Neurosci 13:2651-2661.

Dilsaver SC, Majchrzak MJ, Alessi NE (1990) Telemetric measurement of core temperature in pharmacological research: validity and reliability. Prog Neuro-Psychopharmacol Biol Psychiatry 14:591-596.

Dilsaver SC, Overstreet DH, Peck JA (1992) Measurement of temperature in the rat by rectal probe and telemetry yields compatible results. Pharmacol Biochem Behav 42:549-552.

Farfel GM, Seiden LS (1995a) Role of hypothermia in the mechanism of protection against serotonergic toxicity. I. Experiments using 3,4methylenedioxymethamphetamine, dizocilpine, CGS19755 and NBQX. J Pharmacol Exp Ther 272:860-867.

Farfel GM, Seiden LS (1995b) Role of hypothermia in the mechanism of protection against serotonergic toxicity. II. Experiments with methamphetamine, p-chloroamphetamine, fenfluramine, dizocilpine and dextromethorphan. J Pharmacol Exp Ther 272:868-875.

Friedman R (1993) Ecstasy, the serotonin syndrome, and malignant hyperthermia-a possible link [reply to letter]? JAMA 269:269-270.

Ginsberg MD, Sternau LL, Globus MY, Dietrich WD, Busto R (1992) Therapeutic modulation of brain temperature: relevance to ischemic brain injury. Cerebrovasc Brain Metab Rev 4:189-225.

Globus MY, Busto R, Lin B, Schnippering H, Ginsberg MD (1995) Detection of free radical activity during transient global ischemia and recirculation: effects of intraischemic brain temperature modulation. J Neurochem 65:1250-1256.

Gordon CJ (1993) Temperature regulation in laboratory animals. New York: Cambridge UP.

Gordon CJ, Fogelson L (1994) Metabolic and thermoregulatory responses of the rat maintained in acrylic or wire-screen cages: implications for pharmacological studies. Physiol Behav 56:73-79.

Gordon CJ, Watkinson WP, O'Callaghan JP, Miller DB (1991) Effects of 3,4-methylenedioxymethamphetamine on autonomic thermoregulatory responses of the rat. Pharmacol Biochem Behav 38:339-344.

Green AR, Cross AJ, Goodwin GM (1995) Review of the pharmacology and clinical pharmacology of 3,4-methylenedioxymethamphetamine (MDMA or “ecstasy”). Psychopharmacology 119:247-260.

Gudelsky GA (1996) Effect of ascorbate and cysteine on the 3,4methylenedioxymethamphetamine-induced depletion of brain serotonin. J Neural Transm 103:1397-1404.

Halliwell B (1992) Reactive oxygen species and the central nervous system. J Neurochem 59:1609-1623.

Henry JA (1992) Toxicity and deaths from 3,4-methylenedioxymethamphetamine ("ecstasy"). Lancet 340:384-387.

Illievich UM, Zornow MH, Choi KT, Strnat MA, Scheller MS (1994) Effects of hypothermia or anesthetics on hippocampal glutamate and glycine concentrations after repeated transient global cerebral ischemia. Anesthesiology 80:177-186.

Kaskey GB (1992) Possible interaction between an MAOI and "Ecstasy." Am J Psychiatry 149:411-412.

Kil HY, Zhang J, Piantadosi CA (1996) Brain temperature alters hydroxyl radical production during cerebral ischemia/reperfusion in rats. J Cereb Blood Flow Metab 16:100-106.

Kotake C, Heffner T, Vosmer G, Seiden LS (1985) Determination of dopamine, norepinephrine, serotonin and their major metabolic products in rat brain by reverse phase ion pair high performance liquid chromatography with electrochemical detection. Pharmacol Biochem Behav 22:85-89.

Kramer HK, Poblete JC, Azmitia EC (1995) 3,4-methylenedioxymethamphetamine ("Ecstasy") promotes the translocation of protein kinase $\mathrm{C}(\mathrm{PKC})$ : requirement of viable serotonin nerve terminals. Brain Res 680:1-8.

Kramer HK, Poblete JC, Azmitia EC (1997) Activation of protein kinase $\mathrm{C}$ (PKC) by 3,4-methylenedioxymethamphetamine (MDMA) occurs through the stimulation of serotonin receptors and transporter. Neuropsychopharmacology 17:117-129.

Lew R, Sabol KE, Chou C, Vosmer GL, Richards J, Seiden LS (1996) Methylenedioxymethamphetamine (MDMA)-induced serotonin deficits are followed by partial recovery over a 52 week period. II. Radioligand binding and autoradiographic studies. J Pharmacol Exp Ther $276: 855-865$.
Malberg JE, Seiden LS (1996) 3,4-methylenedioxymethamphetamine (MDMA) 5HT neurotoxicity is a function of ambient temperature and core body temperature in rats. Soc Neurosci Abstr 3:1916.

Malberg JE, Sabol KE, Seiden LS (1996) Co-administration of MDMA with drugs that protect against MDMA neurotoxicity produces different effects on body temperature in the rat. J Pharmacol Exp Ther 278:258-267.

Mazzola-Pomietto P, Aulakh CS, Tolliver T, Murphy DL (1997) Functional subsensitivity to $5 \mathrm{HT} 2 \mathrm{~A}$ and $5 \mathrm{HT} 2 \mathrm{C}$ receptors mediating hyperthermia following acute and chronic treatment with $5 \mathrm{HT} 2 \mathrm{~A} / 2 \mathrm{C}$ receptor agonists. Psychopharmacology 130:144-151.

McCann UD, Slate SO, Ricaurte GA (1996) Adverse reactions with 3,4-methylenedioxymethamphetamine (MDMA; "Ecstasy"). Drug Saf 15:107-115.

Miller DB, O'Callaghan JP (1994) Environment-, drug- and stressinduced alterations in body temperature affect the neurotoxicity of substituted amphetamines in the C57BL/6J mouse. J Pharmacol Exp Ther 270:752-760.

Mitani A, Kadoya F, Kataoka K (1991) Temperature dependence of hypoxia-induced calcium accumulation in gerbil hippocampal slices. Brain Res 562:159-163.

Nash JF, Meltzer HY, Gudelsky GA (1988) Elevation of serum prolactin and corticosterone concentrations in the rat after the administration of 3,4-methylenedioxymethamphetamine. J Pharmacol Exp Ther 245:873-879.

Nash JF, Roth BL, Brodki JD, Nichols DE, Gudelsky GA (1994) Effect of the $\mathrm{R}(-)$ and $\mathrm{S}(+)$ isomers of MDA and MDMA on phosphotidylinositol turnover in cultured cells expressing 5HT2A and 5HT2C receptors. Neurosci Lett 177:111-115.

O'Hearn E, Battaglia G, DeSouza EB, Kuhar MJ, Molliver ME (1988) Methylenedioxyamphetamine (MDA) and methylenedioxymethamphetamine (MDMA) cause selective ablation of serotonergic axon terminals in forebrain: immunocytochemical evidence for neurotoxicity. J Neurosci 8:2788-2803.

Rudnick G, Wall SC (1992) The molecular mechanism of "ecstasy" [3,4methylenedioxy-methamphetamine (MDMA)]: serotonin transporters are targets for MDMA-induced serotonin release. Proc Natl Acad Sci USA 89:1817-1821.

Sabol KE, Lew R, Richards JB, Vosmer GL, Seiden LS (1996) Methylenedioxymethamphetamine (MDMA)-induced serotonin deficits are followed by partial recovery over a 52 week period. I. Synaptosomal uptake and tissue concentrations. J Pharmacol Exp Ther 276:846-854.

Schmidt CJ (1987) Neurotoxicity of the psychedelic amphetamine, methylenedioxymethamphetamine. J Pharmacol Exp Ther 240:1-7.

Schmidt CJ, Wu L, Lovenberg W (1986) Methylenedioxymethamphetamine: a potentially neurotoxic amphetamine analogue. Eur J Pharmacol 124:175-178.

Seiden LS, Vosmer G (1984) Formation of 6-hydroxydopamine in caudate nucleus of the rat brain after a single large dose of methylamphetamine. Pharmacol Biochem Behav 21:29-31.

Sonsalla PK, Nicklas WJ, Heikkila RE (1989) Role for excitatory amino acids in methamphetamine-induced nigrostriatal dopaminergic toxicity. Science 243:398-400.

Spanos LJ, Yamamoto BK (1989) Acute and subchronic effects of methylenedioxymethamphetamine [ \pm ) MDMA] on locomotion and serotonin syndrome behavior in the rat. Pharmacol Biochem Behav 32:835-840.

Sporer KA (1995) The serotonin syndrome. Drug Saf 13:94-104.

Steele TD, McCann UD, Ricaurte GA (1994) 3,4-Methylenedioxymethamphetamine (MDMA; "Ecstasy"): pharmacology and toxicology in animals and humans [review]. Addiction 89:539-551.

Sternbach H (1991) The serotonin syndrome. Am J Psychiatry 148:705-713.

Stone DM, Johnson M, Hanson GR, Gibb JW (1988) Role of endogenous dopamine in the central serotonergic deficits induced by 3,4methylenedioxymethamphetamine. J Pharmacol Exp Ther 247:79-87.

Wilkinson LO, Auerbach SB, Jacobs BL (1991) Extracellular serotonin levels change with behavioral state but not with pyrogen-induced hyperthermia. J Neurosci 11:2732-2741.

Zeevalk GD, Nicklas WJ (1993) Hypothermia, metabolic stress and NMDA-mediated excitotoxicity. J Neurochem 61:1445-1453. 